ISSN: 2458-7508

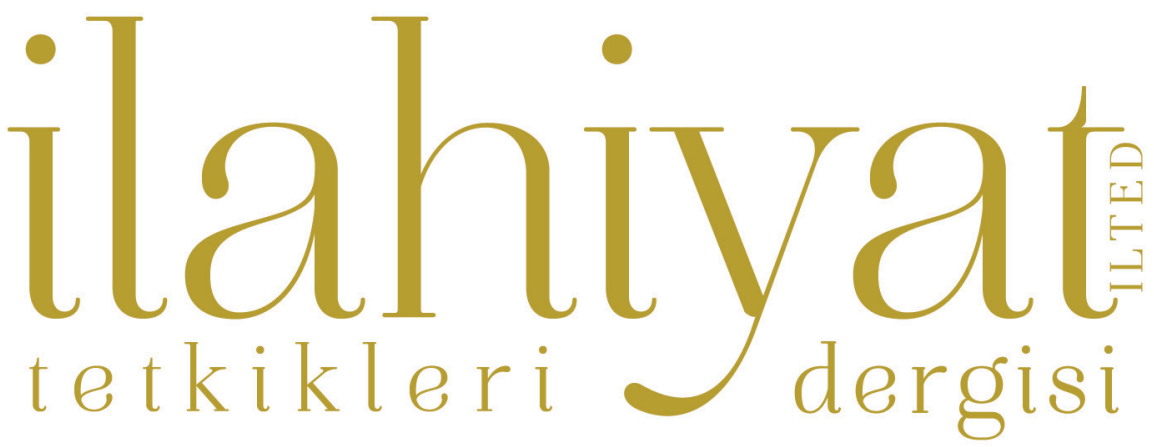

Journal of Ilahiyat Researches

ATATÜRK ÜNIVERSITESI

İLAHİYAT FAKÜLTESİ

YIL: 2017 | SAYI: 47

ERZURUM

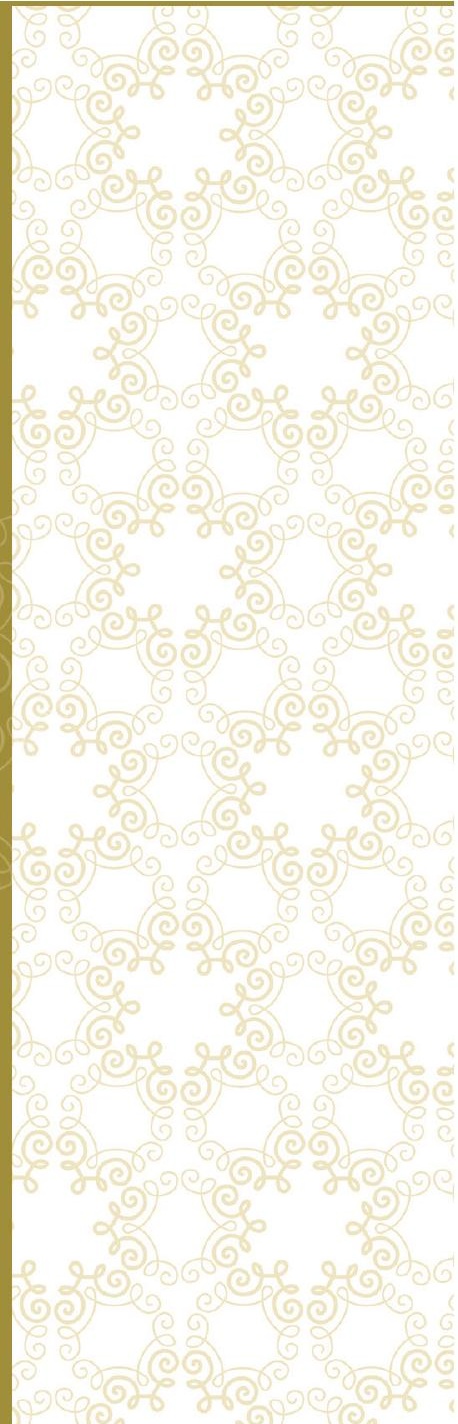




\section{Sahabe Gözünde Kudüs ve Mescíd-í Aksâ}

\section{İsmail ALTUN*}

\section{ÖZ}

Peygamberler diyarı Kudüs, İslâm'da özel bir yere ve kudsiyete sahiptir. Müslümanların ilk kıblesi olması ve Allah Resûlünün İsrâ gecesinde içine girip namaz kıldiğı Mescid-i Aksầy bünyesinde barındırması sebebiyle Kudüs, evvela sahabenin sonra da bütün İslâm âleminin ilgi odağı hâline gelmiştir.

Bu makalede, faziletine dair ayet ve hadislerin bulunduğu, tarihî ve manevî değeri yüksek yerlerden biri olan Kudüs topraklarına ve Mescid-i Aksâya gerek Hz. Peygamber döneminde gerekse $H z$. Peygamber'in vefatından sonra sahabenin gösterdiği ilgi ve bu ilginin sebepleri üzerinde durulacaktır. Ayrica sahabenin Mescid-i Aksầya ve İsrâ hadisesine fazla önem vermediğine veya ilgi göstermediğine dair günümüzde ileri sürülen bazı farklı görüş ve iddialar eleştirel bir bakış açısıyla ele alınıp değerlendirilecek, bu görüş ve iddiaların ne derece doğru veya tutarlı olduğu ortaya konulmaya çalışılacaktır.

Anahtar kelimeler: Sahabe, Kudüs, Mescid-i Aksâ, Beytü’l-Makdis.

\section{ABSTRACT}

\section{Jerusalem and Al-Masjid Al-Aqsa According to the Companions of the Prophet}

Jerusalem, the land of prophets, has a special place and holiness in Islam. It became the focus of interest, primarily for the Companions of the Prophet (PBUH) and also for the whole Islamic world; due to the fact that it was the first qibla (the direction of worship) and also it is the city in which the Masjid al-Aqsa takes place, where the Messenger of Allah (PBU) had entered into it and had worshipped on the night of Isra (journey from Mecca to Jerusalem).

In this article, we will dwell on the interest shown by the Companions for the city of Jerusalem and for Masjid al-Aqsa - about which, there are verses from Quran and hadiths (prophetic narrations) regarding their value and a place having a high historical and spiritual importance-, both at the time of the Prophet (PBUH) and following his death and reasons of this interest. Furthermore, we will also deal with different modern views and claims; asserting that the Companions had not paid due attention or shown interest for Masjid al-Aqsa or the event of Isra (journey from Mecca to Jerusalem); we will exhibit a critical approach on the matter and try to put forward an evaluation on the accuracy or consistency of those views and claims.

Keywords: Companions of the Prophet, Jerusalem, al-Masjid al-Aqsa, Bait al-Maqdis. 


\section{Giriş}

İnsanlık tarihinin kadim şehirlerinden biri olan ve günümüze kadar varlığını koruyan Kudüs, başta Hz. Peygamber ve sahabe olmak üzere bütün İslâm dünyası için dinî bir merkez hüviyetindedir. Bu itibarla Hz. Peygamber ve sahabiler, gerek tarihî ve kültürel dokusuyla İslamî bir geçmişi olan Kudüse, gerekse bu şehrin göz bebeği olan ve hâsseten Kurân-1 Kerim'de ve hadis-i şeriflerde zikri geçen Mescid-i Aksâyya ${ }^{1}$ özel ilgi göstermişlerdir. Hz. Peygamber'in vefatından sonra da sahabiler, Kudüs’e olan ilgilerini devam ettirmiş, buraya sahip çıılması gerektiğinin bilinciyle hareket etmişlerdir. Nihayet bu mukaddes belde, Hz. Ömer'in hilafeti döneminde fethedilmiştir. Fetihten sonra da bu ilgi inkıtaya uğramamış, sahabe Kudüs'e ve Mescid-i Aksâya fevkalâde ehemmiyet vermeye ve rağbet göstermeye devam etmişlerdir.

Ancak günümüzde, sahabenin Kudüs'e ve Mescid-i Aksầya hususi bir ehemmiyet vermediklerine veya fazla rağbet göstermediklerine dair görüş ve iddialar ortaya atılmıştır. Nitekim bir araştırmacı, fetih esnasında Hz. Ömer'in ve sahabenin, 'Mescid-i Aksâ burasıdır, ilk kıblemiz burasıdır' diyerek Kudüs’e özel ilgi göstermediklerini ve buraya hususi bir bölge muamelesi yapmadıklarını öne sürmüștür. Fetih sonrası halifenin ve sahabenin Mescid-i Aksâyı bulma ve yerini tespit etme konusunda bir gayretlerinin olmadığını ve bu mescide tazim ettiklerine ya da önem verdiklerine dair kaynaklarda herhangi bir bilginin yer almadığını iddia etmiştir. ${ }^{2}$ Böylece $\mathrm{Hz}$. Peygamber'in İsrâ gecesi Kudüs’e yürütülmediğini ve Mescid-i Aksânın Kudüs’te bulunamayacağını ispat etmek istemiştir.

Bir başka araştırmacı ise Hz. Ömer'in Kudüs'ü önemsediğini belirtmiş ancak bazı klasik kaynaklarda Hz. Ömer'in ve sahabenin İsrâ hadisesini bu bölgeyle ilişkilendirdiklerine dair herhangi bir bilginin bulunmadığını ileri sürmüștür. Bunun sebebini

1 Hz. Âdem döneminde te'sis edilen, Hz. Süleyman zamanında ise tecdid edilen Mescid-i Aksâ, daha sonraki dönemlerde çeşitli yıkımlara maruz kalmıştır. Hz. Peygamber döneminde Kudüs'te bugünkü şekliyle yer alan kubbeli bir mabed bulunmamaktadır. Bkz. İsmail Altun, "Hz. Peygamber döneminde Kudüs’te Mescid-i Aksâ Var mıydı?" Turkish Studies, Karşılaştırmalı Dinî Araştırmalar (Comparative Religious Studies), Ankara-Winter 2017, c. 12, sayı, 2, ss.1-22, s. 8, 15. Fakat bir mekânın mescid olarak isimlendirilmesi için etrafının duvarlarla örülmüş olması şart değildir. Nitekim Hz. Peygamber döneminde Kâbe’nin etrafı duvarlarla örülmüş değildir. Kâbe’nin etrafı ilk olarak Hz. Ömer döneminde duvarla kușatılmıștır. Bkz. Belâzürî, Ebu'l-Abbas Ahmed b. Yahya, Fütûhu'l-Büldân, thk. Abdullah Enis et-Tübbâ'-Ömer Enis et-Tübbâ', Beyrut, 1987, s. 62. Ancak duvarlarla çevrilmeden önce de Kâbenin etrafını oluşturan boş alana Mescid-i Haram ismi verilmiştir. Bkz. Bakara, 2; 144, 149, 150, 191, 196, 217; Maide, 5; 2; Enfal, 8; 34; Tevbe, 9; 7, 19, 28; İsra, 17; 1; Hac, 22; 25; Fetih, 48; 25, 27. Tipk1 bunun gibi İsrâ hadisesinin gerçekleştiği dönemde temelleri bulunan ve mekânı bilinen Süleyman mabedinin, daha önce üzerine bina edildiği boș alana Mescid-i Aksâ ismi verilmiștir. Filhakika İslâm’ın ilk dönemlerinde Mescid-i Aksâ tabiri ile özellikle etrafı surlarla kuşatılmış olan Harem alanı yani sahra/hacer-i muallak ve etrafındaki ibadet alanı kastedilmiştir. Harem alanının içerisine ise sûr kapılarından girilmektedir ve Hz. Peygamber İsrâ gecesinde bu kapıların birinden mescide girip namaz kılmıştır. Bunun için bu kapı "Muhammed kapısı" olarak isimlendirilmiştir. Geniş bilgi ve değerlendirmeler için bkz. Altun, "Hz. Peygamber döneminde Kudüs'te Mescid-i Aksâ Var miydı?” s. 15, 16, 18.

2 Mehmet Azimli, Siyeri Farklı Okumak, Mekke Yılları, Ankara Okulu Yayınları, Ankara, 2010, s. 165; A. Mlf. İsrâ ve Miraç Olayları Üzerine Bazı Mülahazalar, Bilimname: Düşünce Platformu, 2009/1, cilt: VII, sayı: 16, ss. 4358, s. 48-49. 
de sonraki dönemlerde olduğunun aksine erken dönemlerde Müslümanların İsrâ hadisesine fazla önem vermemelerine bağlamıştır. ${ }^{3} \mathrm{Bu}$ anlayışa göre $\mathrm{Hz}$. Ömer ve sahabe, Kudüs'ü önemsemiş fakat İsrâ hadisesine fazla önem vermemişlerdir.

Kimi şarkiyatçılar da Müslümanların, Emeviler döneminden itibaren Emevi halifesi Abdu'l-Melik'in sarfettiği gayretler neticesinde Kudüse önem vermeye başladıklarını ileri sürmüşlerdir. Nitekim Macar şarkiyatçısı Yahudi Goldzihere göre, Emevi halifesi Abdu'l-Melik b. Mervan (ö. 86/705), kendisiyle hilafet mücadelesinde bulunduğu Abdullah b. Zübeyr'in hâkimiyetindeki Mekke’ye mukabil kendi hâkimiyetindeki Kudüse kudsiyet kazandırmak maksadıyla meşhur hadis imamlarından İbn Şihab ez-Zühri (ö. 124/742)'ye hadis uydurma görevi vermiştir. ${ }^{4}$ Kezâ Alman şarkiyatçısı Yahudi J. Horovitz, Kur’an'da zikri geçen Mescid-i Aksẩnın yerinin Kudüs’te gösterilmiş olmasının, Abdu'l-Melik'in müminler nazarında Kudüs’e hususi bir ehemmiyet kazandırmak bakımından sarfettiği gayretlerle ilgili olduğunu iddia etmiştir. İ́slam Ansiklopedisi'ndeki "Kudüs" maddesinin yazarı Hollandalı şarkiyatçı B. Schrieke'ye göre ise muahhar kaynaklar açık bir sebebe dayanmaksızın Mescid-i Aksầyı Kudüs olarak almışlardır. Schrieke, Abdullah b. Zübeyr’in hâkim olduğu Mekkeye karşı Kudüsü şerefli göstermek isteyen Emevi siyasetinden mülhem tarafgir bir te’vil neticesinin ürünü olarak Mescid-i Aksẩnın Kudüs'te gösterildiğini ileri sürmüştür. ${ }^{6} \mathrm{Bu}$ iddialardan, Müslümanların Emeviler dönemine kadar Kudüs'ü pek fazla önemsemedikleri, Emevi halifesi Abdu'l-Melik'in Mescid-i Aksẩnın yerini Kudüs'te göstermesinden itibaren bu topraklara hususi bir ehemmiyet vermeye başladıkları gibi bir anlam ortaya çıkmaktadır.

$\mathrm{Bu}$ çalışmanın hazırlanmasındaki esas gaye, Hz. Peygamber'in vefatından sonra sahabenin ve Hz. Ömer' in Kudüse ve Mescid-i Aksâya özel ilgi gösterip göstermediklerini, şayet göstermişlerse bu yakın ilginin hangi sebeplerden kaynaklandığını ortaya koymaktır. Ayrıca sahabenin fetih sonrasında Kudüs'e ve Mescid-i Aksâya özel ilgi göstermediklerine veya Kudüs'ü önemsedikleri halde İsrâ hadisesine fazla önem vermediklerine dair günümüzde ileri sürülen farklı görüş ve iddiaları ele alıp değerlendirmeye tabi tutmaktır. Kezâ Emevi halifesi Abdu'l-Melik'in, müminler nazarında Kudüs'e hususi bir ehemmiyet kazandırmak maksadıyla Mescid-i Aksânın yerini Kudüs'te gösterdiğine dair şarkiyatçılar tarafından ortaya atılan iddialara cevap aramaktır. Çalışmamızın, başta İsrâ ve Miraç olmak üzere bir kısım tarihî hadiselerin daha doğru anlaşılmasına katkı sağlayacağını ümit ediyoruz. Konuyu fetih öncesi ve fetih sonrası sahabe gözünde Kudüs ve Mescid-i Aksâ olmak üzere iki ayrı başlık halinde ele almak uygun olacaktır.

3 İsrâfil Balc1, İsrâ ve Mirâc Gerçeği, Ankara, 2014, s. 125-129.

4 Goldziher, I., Muslim Studies, İngilizceye çev. C. R. Barber-S. M. Stern, New York Üniversitesi Yayınları, İngiltere, 1971, s. 44-45.

5 J. Horovitz, 'Mi’râc', İA, İstanbul, 1979, VIII, 344-45.

6 B. Schrieke, 'İsrâ', İA, İstanbul, 1987, V/II, 1126. 


\section{Fetih Öncesi Sahabe Gözünde Kudüs ve Mescid-i Aksâ}

Kur'an-1 Kerim'de ismi doğrudan zikredilmeyen ancak müteaddid ayetlerde bereketli kılındığ $1^{7}$ ve mukaddes olarak vasıflandırıldığ $1^{8}$ anlaşılan Kudüs, Müslümanların ilk kıblesidir. Bilindiği gibi Allah Resûlü ve sahabe hicretten önce Mekke'de, hicretten sonra da 16 ay kadar Medine'de namazlarını Beytü'l-Makdise yönelerek kılmışlardır. ${ }^{9}$ Özellikle İsrâ hadisesinden sonra sahabiler, bu mukaddes beldeye yoğun ilgi göstermiş, Hz. Peygamber (as)'in vefatı sonrasında ise Kudüs'ü fethetmeyi amaçlamışlardır. ${ }^{10}$ Çünkü Resûlullah, vefatından hemen önce Beytü'l-Makdis'in yakında fethedileceğini müjdelemiş ${ }^{11}$ hatta Şam/Filistin topraklarına gönderilmek üzere Üsâme b. Zeyd komutasında bir ordu hazırlatmıştır. Bu sebeple sahabiler Allah Resûlü'nün vefatının hemen ardından Kudüs topraklarını fethe yönelmişlerdir. Filistin bölgesinin önemli bir kısmı, Hz. Ebû Bekir döneminden itibaren Müslümanların hâkimiyetine girmiştir. Hz. Ebû Bekir'in Filistin cephesi komutanı Amr b. el-Âs, başta Gazze ve Nablus olmak üzere birçok kenti Hıristiyan Bizans'tan alarak İslam topraklarına katmış ${ }^{12}$ ve Kudüs önlerine kadar gelmiştir. Hz. Ebû Bekir döneminde ilk fethedilmesi gereken yerlerden biri olarak görülen Kudüs, nihayet $\mathrm{Hz}$. Ömer döneminde 17/638 yılında Ebu Ubeyde b. Cerrâh komutasındaki İslâm askerlerinin gayretleriyle Bizanslılardan teslim alınmış ve İslâm topraklarına dâhil edilmiştir. ${ }^{13}$ Ayrıca Hz. Peygamber döneminden itibaren bazı sahabiler ibadet ve ziyaret maksadıyla Mescid-i Aksầya özel yolculuklar yapmışlardır. ${ }^{14}$

Bu bilgiler 1şı̆̆ında Kudüs’ün, Mekke döneminden itibaren sahabenin ilgi odağ 1 haline geldiğini onların gözünde ve gönlünde bu toprakların müstesna bir yere sahip olduğunu ifade etmek mümkündür. ${ }^{15}$ Denebilir ki Hz. Ömer zamanında gerçekleşecek

$7 \quad$ 7. Araf, 137; 17. İsrâ, 1; 21. Enbiya, 71, 81; 34. Sebe, 18.

8 5. Maide, 21 .

9 Taberî, Ebû Cafer Mummed b. Cerîr, Târîhu'r-Rusûl ve'l-Mulûk, thk. Muhammed Ebu’l-Fadl İbrahim, Kahire, 1119, II, 417 (I, 1281).

10 Muhammed Demirci, “Kudus'ün Kısa Tarihi ve Hz. Ömer’in Emannamesi” Mescid-i Aksâ Sempozyumu, İstanbul Barıș Platformu, İstanbul, 2009, s. 95-96.

11 Makdisî, Ziyauddin Muhammed, Fedâilu Beyti'l-Makdis, thk. Muhammed Mutî’ el-Hâfiz, Dâru'l-Fikr, Dımaşk, 1405, s. 69; Heysemî, Nureddin Ali b. Ebî Bekr, Mecmau'z-Zevâid ve Menbau'l-Fevâid, Beyrut, 1967, IX, 411 (no: 16150); Mucîruddîn el-Hanbelî, el-Ünsü'l-Celîl bi Târîhi'l-Kuds ve'l-Halîl, Amman, 1999, I, 233.

12 Bkz. Belâzürî, Fütûhu'l-Büldân, s.188. Ayrıca bkz. Mahfuz Söylemez, Kudüs ve Osmanlı Arşiv Vesikaları Işs̆ğında Yahudilerin Bölgeye Yerleşmeleri Üzerine Notlar, Siirt Üniversitesi iİahiyat Fakültesi Dergisi, cilt: 1, sayı 2, ss. 33-56, s. 35.

13 Belâzürî, Fütûhu'l-Büldân, s. 189; Taberî, Târîh, IV, 68 (I, 2528).

14 Bkz. İbn Teymiye, Mecmûu'l-Fetâvâ, thk. Amir el-Cezzar, byy, 2005, XXVII, 141; Mucîruddîn el-Hanbelî, elÜnsü'l-Celîl bi Târîhi'l-Kuds ve’l-Halîl, I, 231-37; Tarık Ahmed Hicazi, Şia ve Mescid-i Aksâ, Konya, 2010, s. 54, 57; Ahmet Güç, “Yeryüzünde Üç Büyük Mescid”, Uludă̆ Üniversitesi İlahiyat Fakültesi Dergisi, 1993, cilt: V, say1: 5, s. 270.

15 Filhakika Kudüs sadece sahabe için değil, Wellhausen’’n da işaret ettiği gibi sahabeden önceki bütün Müslümanlar için mukaddes bir belde idi. Wellhausen bu gerçeği șu ifadelerle dile getirmektedir: "Burası (Kudüs), sadece Yahudi ve Hıristiyanların değil, en eski devrinde bütün Müslümanların en mukaddes yeri idi. "Bkz. Wellhausen, J., Arap Devleti ve Sukutu, çev. Prof. Dr. Fikret Işıltan; İlahiyat Fakültesi Yayınlarından, Ankara 1963, s. 101. 
olan Kudüs fethinin hikâyesi, Müslümanların namazlarını Beytü’l-Makdis’e yönelerek kıldıkları andan itibaren başlamıştır. Binaenaleyh sahabenin henüz fetihedilmeden önce Kudüs’e ve Mescid-i Aksầya hususi ilgi gösterdiği saraheten anlaşılmaktadır. Bu ilginin sebeplerini şu şekilde sıralamak mümkündür:

1 Kudüs topraklarının faziletini bildiren ayetler, sahabenin dikkatini bu topraklar üzerine çekmiştir. Kur’an-1 Kerim'de, Kudüs topraklarının faziletine dair birçok ayet vardır. Bu ayetlerden beş tanesi Kudüs topraklarının bereketli kılındığını ifade ederken, ${ }^{16}$ biri de bu toprakları el-Ardu'l-Mukaddese olarak nitelemektedir. ${ }^{17}$ $\mathrm{Bu}$ iki vasıf kullanmaksızın Kudüs'e işaret eden daha başka ayetler de vardır. ${ }^{18}$

2 Kudüs'ün en önemli özelliği Peygamberlik yurdu olmasıdır. ${ }^{19}$ Çok sayıda peygamberin yaşadığı mukaddes bir mekân olması ve peygamberlerden miras kalan Beytü'l-Makdis'i içerisinde barındırması açısından da Kudüs, ${ }^{20}$ sahabenin gözünde önemli bir yere sahip olmuştur.

3 Sahabenin Kudüs'e gösterdiği ilginin sebeplerinden biri de Mescid-i Aksânın etrafının mübarek kılınması ve bu mescidin, Allah’’n yeryüzündeki ilâhi âyetlerinden bir kısmını bünyesinde veya çevresinde barındırmasıdır. Dolayısıyla, Mescid-i Aksâ sıradan bir mekân değil içerisinde veya çevresinde bir kısım harikaları barındıran mübarek bir mescittir. Âyet-i kerimede şöyle buyrulmaktadır: "Kulunu, kendisine birtakım ayetlerimizi göstermemiz için bir gece Mescid-i Harâm'dan çevresini mübarek kıldığımız Mescidi Aksâya yürütenin şanı pek yücedir. Şüphesiz o herşeyi işitendir, görendir." ${ }^{21}$ Yusuf el-Kradâvînnin de belirttiği gibi Kur'ân, Mescid-i Aksầnın önem ve bereketini Mescid-i Nebevî inşa edilmeden ve hatta hicretten birkaç sene önce ilan etmiştir. Hadis-i şeriflerle de Kurân'ın ilan ettiği bu husus teyid edilmiştir. ${ }^{22}$

4 Mescid-i Aksânın Mescid-i Harâm'dan sonra yeryüzünde inşa edilen ikinci mescid olması, sahabenin Kudüs topraklarına önem vermesinin sebepleri arasında zikredilebilir. Nitekim hadis kaynaklarının birçoğunda nakledilen sahih bir hadise göre, Ebû Zer el-Ğifârî (ra) şöyle demiştir: "Bir gün Allah Resûlü’ne; 'Ey Allah’in Resulü! Yeryüzünde ilk önce hangi mescit inşa edilmiştir?' diye sordum. Resûlullah; 'Mescid-i Harâm.' buyurdu. 'Sonra hangisi' diye sordum.

Bkz. 7. A’râf, 137; 17. İsrâ, 1; 21. Enbiyâ, 71, 81; 34. Sebe’, 18.

5. Mâide, 21.

18 Bkz. 2. Bakara, 58, 259; 3. Âl-i İmran, 37-39; 10. Yunus, 93; 19. Meryem, 16-17; 23. Muminun, 50. Kudüs ve Mescid-i Aksâ ile ilgili ayetler hakkında geniş bilgi ve değerlendirmeler için bkz. Cabarin, Raid Fethi Halid, "Tarihî Süreçte Mescid-i Aksâ”, Çağdaş Araştırmalar Merkezi (Merkez Dirasat al-Muasarah) Arapçadan çev. Suna Demir, Mescid-i Aksâ Sempozyumu, İstanbul Barış Platformu, İstanbul, 2009, s. 40-47. 
'Mescid-i Aksâ.' buyurdu. ${ }^{23}$ Ben;'İkisi arasında kaç (yıl fark) vardır?', dedim. Bunun üzerine; 'Kırk yıl.' şeklinde karşılık verdi ve ilave etti: Nerede namaz vaktine ulaşırsan orada namazını kıl, orası mescittir." 24

5 Bilindiği üzere Kudüs, Müslümanların ilk kıblesidir. Kıble Kâbe’ye döndürülmeden önce Müslümanlar, namazlarını belli bir müddet Beytü'l-Makdis'e yönelerek kılmışlardır. ${ }^{25} \mathrm{Bu}$ durum sahabenin dikkatini bir dönem oraya tevcih etmiş ve müslümanların bu şehri dinî bir merkez olarak görmelerinin sebeplerinden birini teşkil etmiştir. ${ }^{26}$ Müslümanlara yüzlerini Mescid-i Haram’a çevirmelerini emreden Kurân ayetleri ininceye kadar Kudüs, Müslümanların kıblesi olmaya devam etmiştir. Bu ayetlerden birinde Hz. Peygamber'e ve ashabına hitaben şöyle buyrulmaktadır: "Biz senin yüzünün semaya doğru çevrilip durduğunu muhakkak görüyoruz. Artık seni hoşnud olacă̆ın bir kıbleye muhakkak tevcih edeceğiz. Haydi, yüzünü Mescid-i Haram tarafina döndür. Ve her nerede bulunursanız yüzlerinizi onun tarafına tevcih ediniz. Ve şüphe yok ki kendilerine kitap verilmiş olanlar da bunun Rabbleri tarafindan hak olduğunu elbette bilirler. Ve Allah onların amellerinden gâfil değildir." ${ }^{27}$ Bir başka ayette de "Her nereden yola çıkarsan yüzünü Mescidi harama doğru çevir ve her nerede olsanız yüzünüzü ona doğru çevirin..." ${ }^{\text {s8 }}$ buyrulmaktadır. Bu ayetler Medine döneminde Hz. Peygamber ve ashabının Mescid-i Kıbleteyn (iki kıbleli mescid)'de namaz kıldıkları esnada nazil olmuştur. Dolayısıyla Müslümanlar vakit namazının bir bölümünü Kudüs'e, bir bölümünü de Mekke’ye doğru yönelerek kılmışlardır. ${ }^{29}$

6 İsrâ ve Mi’râc hadisesi Kudüs'ün kıymetini sahabe gözünde bir kat daha artırmıştır. Resûlullah (as) hicretten önce İsrâ suresinin birinci ayetinde de zikredildiği gibi bir gece Mescid-i Harâm'dan çevresi mübarek kılınan Mescidi Aksầya yürütülmüştür. Allah Resûlü (as) Cibril ile birlikte Beytü’l-Makdis’e girmiş ve orada iki rek’at namaz kılmıştır. ${ }^{30}$ Yüce Allah, yeryüzünde gerçekleşen

23 Abdu’r-Rezzâk, Ebû Bekir, es-Sanânî, el-Musannef, thk. Habîbu’r-Rahman el-A’zamî, Beyrut, 1983, I, 403 (no: 1578), III, 348 (no: 5925); İbn Ebî Şeybe, Ebû Bekir Abdullah b. Muhammed, el-Musannef, thk. Muammed Avvâme, Beyrut, 2006, XIX, 572 (no: 37082); Buhârî, Muhammed b. İsmâîl, Sahîhu'l-Buhârî, İstanbul, 1315, Ehâdîsü'l-Enbiyâ, 10 .

24 Abdu’r-Rrezzâk, el-Musannef, I, 403 (no: 1578), III, 348 (no: 5925); Buhârî, Ehâdîsü’l-Enbiyâ’, 40; Müslim, Ebü’lHüseyn b. Haccâc, Sahîhu Müslim, Riyad, 1998, Mesâcid, 1, 2. Benzer ifadeler için bkz. Malik b. Enes, Muvatta, thk. Muhammed Mustafa el-A’zamî, byy, 2004, I, 266 (no: 360); Ahmed b. Hanbel, Müsned, thk. Şu’ayb Arnavut-Adil Mürşid, Beyrut, 1995, I, 309, V, 157; Buhârî, Ehâdîsü'l-Enbiyâ, 10; İbn Mâce, Ebû Abdillah Muhammed b. Yezîd, Sünen, İstanbul, 1981, Mesâcid, 7; Nesâî, Ahmed b. Şu'ayb, Sünen, thk, Abdu'l-Fettah Ebû Ğudde, Haleb, 1986, Mesâcid, 3.

25 Nesâî, Tefsir, 13.

26 Harman, "Kudüs”, DİA, XXVI, 327.

27 2. Bakara, 144

28 2. Bakara, 150.

29 Yusuf el-Karadavi, Her Müslümanın Ortak Davası Kudüs, s. 14.

30 Müslim, İman, 259, 278. Yakın ifadeler için ayrıca bkz. İbn Ebî Şeybe, el-Musannef, XIX, 244 (no: 37725). Bir araştırmacı İbn Kesir’i referans göstererek sahabe’den Hz. Huzeyfe’nin Hz. Peygamber'in Kudüs'e gittiğini kabul etmediğini ileri sürmektedir. Azimli, Siyeri Farklı Okumak, s. 166 (dipnot). Oysa İbn Kesir'de böyle bir bilgi yer almamaktadır. Hz. Huzeyfe Hz. Peygamber'in Kudüs’e gitmediğini değil, Beytü’l-Makdis'e vardığını ancak orada 
İsrâ yolculuğunun bitiş ve gökyüzünde gerçekleşen Mi'râc yolculuğunun başlangıç noktası olarak Kudüs'ü seçmiştir. ${ }^{31}$

7 Resûlullah'ın, Şam/Filistin topraklarının biran önce fethedilmesini arzulaması, bu maksatla Üsâme ordusunu hazırlatması ve Beytü'l-Makdis'in yakında fethedileceğini ashabına müjdelemesi de Müslümanların Kudüse olan ilgisini iyice pekiştirmiştir. Bilindiği gibi Allah Rasûlü, ömrünün son günlerinde Roma İmparatorluğu’na karşı sefere göndermek üzere büyük bir ordu hazırlayarak genç bir sahâbî olan Üsâme b. Zeyd'i bu ordunun başına geçirmiştir. Ancak Üsâme, ordusuyla hareket etmek üzereyken, Hz. Peygamber dâr-i bekaya irtihal etmiştir. Sahabe, Resûlullah'ın arzusu istikametinde Şam/Filistin topraklarını fethetmek üzere icraata başlamışlardır. Nitekim Hz. Ebû Bekir'in, hilâfet makamına geçtikten sonraki ilk icraatı, Hz. Peygamber'in talimatı gereği Üsâme ordusunu Suriye’ye göndermesi olmuştur. İlk fethedilmesi gereken yerlerden biri olarak görülen Kudüs, Hz. Ebû Bekir döneminde fethedilmek istenmiş, nihayet Hz. Ömer döneminde 17/638 yllında Bizanslılardan alınmış ve İslâm topraklarına dâhil edilmiştir. ${ }^{32}$ Yine Resûlullah, vefatı yaklaştığı günlerde Şeddad b. Evs'i muzdarip ve üzgün görüp onu teselli ederken şu ifadeleri dile getirmiştir: "Âgâh olun! İnşâalah Şam yakında fetholunacaktır. Âgâh olun! İnşâalah Beytü'l-Makdis de yakında fetholunacaktır. Sen ve senden sonra da çocuğun orada inşâallah imamlar olacaksınız."33 Resûlullahỉn verdiği müjde tahakkuk etmiş ve bu sevindirici haberden yaklaşı altı yıl sonra Beytü'l-Makdis fetholunmuşstur. Şeddâd da hicretin 58. senesinde 75 yaşında vefat etmiş ve oraya defnedilmiştir. Kabri Mescid-i Aksânın surlarının altındaki Bâbu'r-Rahme (Rahmet Kapısı) kabristanındadır. ${ }^{34}$ Yine Ebû Ümâme elBahilînin anlattığına göre Hz. Peygamber (sav) şöyle buyurmuştur: "Ümmetimden bir topluluk, galip oldukları halde kendilerine Allahin emri gelinceye kadar düşmanların kahretmeye devam edeceklerdir ve başlarına gelen hastalıklar dışında hiçbir düşman onlara zarar veremeyecektir" Orada bulunanlar, "Yâ Resûlallah! Bu kimseler nerede olacaklar?" diye sordular. Hz. Peygamber, "Beytü’l-Makdis'te ve onun çevresinde olacaklar" buyurdu. ${ }^{35}$ İbn Ömer ile Ebû Hureyre'den rivayet edilen bir başka sahih hadiste ise Allah Resûlü, Müslümanlarla Yahudiler

namaz kılmadığını ifade etmiştir. Bkz. İbn Ebi Şeybe, el-Musannef, XX, 248 (no: 37728); Ahmed b. Hanbel, Müsned, V, 387, 392, 394; Tirmizi, “Tefsiru'l-Kurân", 18; İbn Kesîr, Ebu'l-Fida İsmail, el-Bidaye venn-Nihâye, thk. Abdullah b. Abdu'l-Muhsin et-Türkî, Cîze, 1998, IV, 276; Ancak onun bu sözü de kabul edilmemiştir. Nitekim İbn Kesire göre Huzeyfe’nin bu sözü kabule şayan değildir. Zira Hz. Peygamber'in Beytü’l-Makdis’te namaz kıldığı sabittir. Ayrıca ispatlayıcı nass, reddedici nassa tercih edilir. Bkz. İbn Kesir, Ebu'l-Fida İsmail, Tefsîru'l-Kurâni'lAzîm, thk. Mustafa Seyyid Muhammed ve Arkadaşları, Kahire, 2000, VIII, 400; A. Mlf., el-Bidâye, IV, 276. 
arasında gerçekleşecek savaşı da haber vermiştir. Zaferin, neticede Müslümanların olacağını, öyle ki, ağaçların ve taşların bile Müslümanların safında durup onlara düşmanın saklandığı yeri söyleyeceğini müjdelemiştir. ${ }^{36} \mathrm{Bu}$ hadisi şeriflerde Kudüs şehrinin düşmanlar -özellikle de Yahudiler- tarafından zaman zaman işgal edileceği ve büyük bir tehdide maruz kalacağı fakat netice itibariyle galibiyetin Müslümanlara ait olacağı anlatılmaktadır. Hz. Peygamber'in ise ümmetine sürekli olarak bu kutsal şehri korumalarını, düşman eline esir düşmemesi için uğrunda cihad etmelerini ve esir düşmesi halinde ise savaşıp onu özgürlüğüne kavuşturmalarını öğütlediği anlaşılmaktadır. Onun içindir ki Müslümanlar Kudüs'ü ribat ve cihat şehri olarak nitelendirmişlerdir. ${ }^{37}$

8 Sahabenin Kudüs’e gösterdiği özel ilginin bir diğer sebebi, Mescid-i Aksâ’da kılınan namazların, Mescid-i Harâm ve Mescid-i Nebevi hariç diğger mescitlerde kılınan namazlardan daha faziletli olduğuna dair nakledilen hadislerdir. Nitekim mescitlerin en faziletlileri Mescid-i Harâm, Mescid-i Nebevi ve Mescid-i Aksầdır. Hadislerde bildirildiğine göre bu mescitlerde kılınan namazlar, diğer mescitlerde kılınan namazlardan çok daha faziletlidir. ${ }^{38}$ Mezkûr hadislerden birinde şöyle buyrulmaktadır: "Beytü'l-Makdis'te/Mescid-i Aksâdda kılınan namaz, Mescid-i Harâm, Mescid-i Nebevi haricindeki mescitlerde kılınan beş yüz namaza denktir." ${ }^{39}$ Yine Resûlullah (as), kendilerine özel yolculuk yapilabilecek üç mescitten birinin Mescid-i Aksâ olduğunu beyan etmiştir. Birçok hadis kitabında sahih olarak nakledilen bir hadisi şerifte Resûlullah (a.s.) şöyle buyurmuştur: "(İbadet kastıyla olan özel) yolculuk, ancak şu mescidden birine olur: Mescid-i Harâmia, Mescid-i Rasûl'e ve Mescid-i Aksâ'ya." ${ }^{0}$ Bazı rivayetlerde Mescid-i Aksâ yerine Beytü'l-Makdis, ${ }^{41}$ bazılarında ise Mescid-i Îliyâ ${ }^{42}$ tabiri kullanılmıştır. ${ }^{43}$ Dolayısıyla Kudüs, Müslümanların nezdinde Mekke ve Medine'den sonra üçüncü kutsal şehir, Mescid-i Aksâ ise Mescid-i Haram ve Mescid-i Nebevi'den sonra üçüncü kutsal mescittir.

36 Müslim, Fiten, 81, 82 (No: 2920, 2921).

37 Bkz. Yusuf el-Karadavi, Her Müslümanın Ortak Davası Kudüs, s. 20, 21.

38 İbn Mâce, İkâmetu's-Salâh, 198; Ayrıca bkz. İbnu'l-Cevzî, Cemalüddin Ebu'l-Ferec, Târîhu Beyti'l-Makdis, byy, tsz. s. 3; A. Mlf., Fedâilü'l-Kuds, Cebrail Süleyman, Beyrut, 1980, s. 88-90.

39 Heysemî, Mecmau'z-Zevâid, III, 675, (IV, 7), (No: 5873).

40 İbn Ebî Şeybe, el-Musannef, VIII, 720 (no: 15785); Ahmed b. Hanbel, Müsned, III, 7; Buhârî, Fadlu’s-Śalât, 1, 6; Benzer ifadeler için bkz. Abdu'r-Rezzâk, el-Musannef, V, 132 (no: 9158, 9159, 9160), İbn Ebî Şeybe, el-Musannef, V, 176 (7620), VIII, 721 (no: 15790, 15792), 722 (no: 15793); Ahmed b. Hanbel, Müsned, II, 278; Buhârî, Cezâu’s-Sayd, 26, Savm, 67; Müslim, Hacc, 15/415, 511, 512; Ebû Dâvûd, Süleyman b. el-Eş’as es-Sicistanî, Sünen, Kahire, 1988, Menâsik, 98; İbn Mâce, İkâmetu’s-Salâh, 196; Tirmizî, Ebû İsa Muhammed b. İsâ, Sünen, nşr. Ahmed Muhammed Şâkir, İstanbul 1981, Śalât, 326; Nesâî, Mesâcid, 10.

41 İbn Ebî Şeybe, el-Musannef, V, 175 (no: 7619), VIII, 720 (no: 15787).

42 Müslim, Hac, 513. Îliyâ, Romalıların Kudüs șehrine verdikleri Latince Aellia isminin Arapçalașmıș şeklidir. Nebi Bozkurt, "Mescid-i Aksâ", DİA, Ankara, 2004, XXIX, 270. Bir başka ifadeyle Arapların Kudüs ya da Beytü'lMukaddes dedikleri yere Yunanca Îliyâ vilayeti denir. Evliya Çelebi, Seyahatname (Kısaltılmış Versiyon), Sadeleştirerek çev. Tevfik Temelkuran-Necati Aktaş- Mümin Çevik), İstanbul, 2006, s. 565.

43 Bu durum bu üç ayrı tabirin aynı yeri ifade ettiğini ve Mescid-i Aksâ’nın Kudüs’te bulunduğunu göstermesi bakımından önemlidir. 
İbn Teymiye, bu hadisin sihhati hususunda ümmetin ittifak ettiğini kaydederken ${ }^{44}$ İslâmî ilimler üzerindeki tetkikleriyle tanınmış Yahudi asıllı Macar müsteşrik Goldziher, mezkûr hadisin mevzû olduğunu iddia etmiştir. Ona göre Emevi halifesi Abdu'l-Melik b. Mervan, kendisiyle hilafet mücadelesinde bulunduğu Abdullah b. Zübeyr’ in hâkim olduğu Mekke’ye karşı Kudüse kudsiyet kazandırmak maksadıyla İbn Şihab ez-Zühri’ye hadis uydurma görevi vermiş ${ }^{45}$, İbn Şihâb ez-Zühri de Abdu'l-Melik'in arzusuna uyarak bu hadisi uydurmuştur. Talat Koçyiğit'in de belirttiği gibi ${ }^{46}$ bu hadisin uydurulduğuna dair Goldziher'in elinde hiç bir delil bulunmamaktadır. Goldziher, bu iddiasını Şiî Ya’kûbînnin Tarihindeki bir rivayete dayandırmış, fakat bu rivayeti de tahrif etmiştir. Çünkü söz konusu rivayette Halife Abdu'l-Melik'in, Zühri'ye hadis uydurma görevi verdiğine dair her hangi bir ibare bulunmamaktadır. ${ }^{47}$ Kaldı ki, Zühri tarafından uydurulduğu iddia edilen mezkûr hadis, daha başka tariklerden de nakledilmiştir. Bunlardan birincisi, Zühri'nin Ebû Hureyre'den rivayeti; ikincisi, Kazaảnın Ebû Sa’id el-Hudri'den rivayeti; üçüncüsü ise, Selman el-Ağarr’n Ebû Hureyre'den rivayetidir. ${ }^{48}$ Goldziher, her nedense, aynı hadisin diğer rivayet şekillerini de hesaba katmamıştır. Bu arada cerh ulemasından hiç birinin Zühri'yi yalancllıkla itham etmediğini ve ondan medh u sena ile bahsettiklerini ${ }^{49}$ hatırlatmış olalım.

9 Sahabenin Kudüs topraklarına yoğun ilgi göstermesinin sebeplerinden biri de Allah Rasûlü’nün Müslümanları Mescid-i Aksầya gidip namaz kılmaya teşvik etmesi ve orada namaz kılmanın mağfirete vesile olacağını müjdelemesidir. İsnadı sahih olan bir hadis-i şerifte ${ }^{50}$ Resûlullah (a.s.) şöyle buyurmuştur: "Süleyman b. Dâvûd (a.s.) Beytü’l-Makdis'i bina ettiğinde Allah Teâlẩdan üç dilekte bulunmuştur. Bunlar, Allahın hükmüne uygun hüküm verme gücü ve kabiliyeti, kendisinden sonra kimselere nasib olmayacak bir mülk ve saltanat ve yalnizca namaz kılmak niyetiyle Mescid-i Aksâya gelenlerin bağışlanmasıdır. Hadisin devamında Hz. Peygamber'in şu açıklaması yer almaktadır: "Cenab-ı Hak, Süleyman'a bunlardan ilk ikisini vermiştir. Üçüncü dileğinin de kabul edilmiş olmasın umarım." ${ }^{51}$ Bir başka hadisi şerifte bildirildiğine göre de Meymûne

İbn Teymiye, Mecmû'u'l-Fetâvâ, XXVII, 105.

Goldziher, Muslim Studies, s. 44-45.

Talat Koçyiğit, I. Goldziher’in Hadisle İlgili Bazı Görüşlerinin Tahlil ve Tenkidi, Ankara Üniversitesi İlahiyat Fakültesi Dergisi, 1967, cilt: XV, s. 49.

Bkz. Ya'kûbî, Târîhu'l-Ya'kûbî, thk. Abdu'l-Emîr Mihnâ, Beyrut, 1993, II, 177-78.

Bkz. Müslim, Hacc, 15/415, 511, 512, 513.

Bu konuda geniş bilgi ve değerlendirmeler için bkz. Talat Koçyiğit, I. Goldziher’in Hadisle İlgili Bazı Görüşlerinin Tahlil ve Tenkidi, s. 43-55.

Kurtubî, Ebû Abdillah Muhammed, el-Câmiu'l-Ahkâmi'l-Kurân, thk. Abdullah b. Abdu'l-Muhsin et-Türkî, Beyrut, 2006, V, 207; Zerkeşî, Muhammed b. Abdillah, I'lâmu's-Sâcid bi Ahkâmi'l-Mesâcid, thk. Ebu'l-Vefa Mustafa el-Merâğ̂̂, Kahire, 1999, s. 29.

Nesâî, Mesacid, 6 (no: 1408). Benzer ifadeler için bkz. Ahmed b. Hanbel, Müsned, II, 176; İbn Mâce, İkametü’sSalâh, 196. İlk iki dilek ayetlerde de zikredilir. Bkz. Sâd 38/35; Enbiya 21/78-79. 
(r.anhâ): "Yâ Resûlallah! Beytü'l-Makdis hakkında bize fetva ver (tavsiyede bulun)" dedi. Resûlullah (as) şöyle buyurdu: 'Oraya gidin ve içinde namaz kılın'. Hadisin râvisi diyor ki: 'O zaman burası Dâru'l-Harb'di'. (Onun için Allah Resûlü sözlerine şöyle devam etti): 'Eğer oraya gidemez ve içinde namaz kılamazsanız kandillerinde yakılmak üzere oraya zeytinyă̆ı gönderin. ${ }^{52} \mathrm{Bu}$ hadiste zikredilen zeytinyağı bir sembol olarak düşünülebilir. Esasında yapılması tavsiye edilen, Kudüs'ün ve Mescidi Aksẩnın önemsenmesi, orada özgürce ibadet edilebilmesi için bu mukaddes beldenin bir an önce İslâmî kimliğe kavuşturulmasının sağlanması ve bu kimliğinin korunması için gayret gösterilmesidir.

\section{Fetih Sonrası Sahabe Gözünde Kudüs ve Mescid-i Aksâ}

Mescid-i Aksâ Hz. Âdem döneminde te’sis edilmiştir. ${ }^{53} \mathrm{~Hz}$. Süleyman zamanında ise tecdid edilmiştir. ${ }^{54} \mathrm{~Hz}$. Süleyman'dan sonraki dönemlerde de çeşitli yıkımlara maruz kalmıştır. Bâbil kralı Buhtunnasır’ın/Nabukadnazar’ın MÖ 587 yılında Kudüs'ü işgali sırasında yağmalanan ve tekrar yakılan Süleyman mâbedi, MÖ 537-515 yılları arasında yeniden yapılmıştır. Kudüs, MÖ 37'de Romalılar'ın Yahudiye kralı ilân ettikleri I. Herod (Büyük Herod) tarafından ele geçirilince mâbed genişletilerek yeniden inşa edilmiştir. Bu inşaat $\mathrm{Hz}$. Îsẩnın doğumundan yirmi yıl kadar önce başlamış ve onun zamanında da sürmüştür. Mezkûr mabed, MS 70 yılında Kudüs'ün Romalılar tarafından kuşatılması esnasında komutan Titus tarafından tekrar tahrip edilmiştir. ${ }^{55}$ Yerine Hadrian döneminde Jüpiter Tapınağı yaptırılmıştır. ${ }^{56}$ Bilahare, Roma’nın Hristiyanlaştığı dönemde o da yıkılmıştır. ${ }^{57}$ Buna rağmen Mescid-i Aksẩnın temelleri ve kapsadığı alanı belirgin bir vaziyette öylece kalmıştır. ${ }^{58}$

Hz. Peygamber'in miraca yükseltildiği zaman Kudüs'te bugünkü şekliyle yer alan dikili bir mabed bulunmamaktadır. ${ }^{59}$ Ancak Hz. Süleyman tarafından bina edilen ve

52 Ebu Dâvûd, Kitâbu’s-Salât, 14.

53 Zerkeși, I'lâmu's-Sâcid bi Ahkâmi'l-Mesâcid, s. 30; Mucîruddîn el-Hanbelî, el-Ünsü'l-Celîl bi Târîhi'l-Kuds ve’lHalîl, I, 8; Ahmed Ömer Haşim, el-Mescidü'l-Aksâ ve Mekânetuhu fi'l-İslâm, Mecelletü'l-Ezher, 53/7, Kahire, 1981, s. 1304; Muhammed Abdu'l-Kerim, Kitâbu'l-Mescidi'l-Aksâ, byy, tsz, s. 14, 17.

54 Kurtubi, el-Câmiu'l-Ahkâmi'l-Kur'ân, V, 207; Ebû Adirrahman es-Selefî, Ebû Adirrahman es-Selefî, İsâdu'lAhissâ bi Zikri Sahihi Fedâili’ş-Şâm ve'l-Mescidi'l-Aksâ, byy, tsz, II, 22; Zerkeși, I’lâmu's-Sâcid bi Ahkâmi'l-Mesâcid, s. 29-30; Mucîruddîn el-Hanbelî, el-Ünsü'l-Celîl bi Târîhi'l-Kuds ve'l-Halîl, I, 9; Ahmed Ömer Haşim, el-Mescidü'l-Aksâ ve Mekânetuhu fi'l-İslâm, s. 1304-05; Ahmet Önkal-Nebi Bozkurt, “Cami”, DİA, İstanbul, 1993, VII, 47.

55 Tanyu, "Ağlama Duvarı", DİA, İstanbul, 1988, I, 474-75; Bozkurt, “Mescid-i Aksâ", DİA, XXIX, 270.

56 Buhl, F., "Kudüs” İA, İstanbul, 1993, VI, 954.

57 İbn Kesîr, el-Bidâye, IX, 656; Muhammed Abdu'l-Kerim, Kitâbu'l-Mescidi'l-Aksâ, s. 20-23; Özcan, Mustafa, "Mescid-i Aksâ ve Üçüncü Mabedin Kaderi" Mescid-i Aksâ Sempozyumu, İstanbul Barış Platformu, İstanbul, 2009, s. 65-66.

58 Raid Salah, "Aksâ Tehlikede", çev. Mustafa Salah, Mescid-i Aksâ Sempozyumu, İstanbul Barıș Platformu, İstanbul, 2009, s. 22-23.

59 Zemahşerî, Ebu'l-Kasım Mahmud b. Ömer, el-Keşşâf an Hakaiki Ğavamidi't-Tenzîl ve Uyûni'l-Ekavîl fî̀ Vucûhi't-Te'vîl, thk. Adil Ahmed-Ali Muhammed, Riyad, 1998, III, 493. 
daha sonra yıkımlara maruz kalan Mescid-i Aksânın temelleri bulunmakta, ${ }^{60}$ mekânı bilinmekte ${ }^{61}$ ve burası Beytü'l-Makdis olarak da isimlendirilmektedir. ${ }^{62}$

Hz. Ömer, Kudüse geldiğinde Süleyman Mabedi’nin sadece enkazı bulunmaktadır. Çünkü Hristiyanlar, reddi mirastan dolayı ve Yahudilerin Hz. Mesihe yaklaşımından ötürü Hz. Dâvûd ve Hz. Süleyman (a.s.)'in mirasına bigâne kalmışlar ve Mescidi kendi hâline terk etmişlerdir. Mescidin bulunduğu mekânı mezbele haline getirmişlerdir. ${ }^{63}$

Kudüs'ün fethinden sonra Hz. Ömer Kudüs patriğinden kendisine Hz. Dâvûd'un mescidini göstermesini talep etmiştir. Patrik, Hz. Ömer’i Beytü'l-Makdis’teki bir kiliseye götürmüş ve buranın Hz. Dâvûd’un mescidi olduğunu söylemiştir. Hz. Ömer, patriğin yalan söylediğini, zira Resûlullah’n daha önce Hz. Dâvûd’un mescidini kendilerine tavsif ettiğini ifade etmiştir. Bunun üzerine Patrik bir başka kiliseyi göstermiş, Hz. Ömer, onu yine yalan söylemekle itham etmiştir. Daha sonra patrik Hz. Ömer ve arkadaşlarını Beytü'l-Makdis mescidine götürmüştür. ${ }^{64} \mathrm{~Hz}$. Ömer, İsrâ gecesi Resûlullah’n girdiği kapıdan Mescide girmiştir. ${ }^{65}$ Mescidi gören Hz. Ömer, tekbir getirmiş ve şunları söylemiştir: "Allah’a yemin olsun ki burası, Resûlullah (as)'in bize anlattığı Dâvûd (as)'un mescididir ki kendisi geceleyin oraya yürütülmüștü.” Sonra Rumların İsrâil Oğullarına öfkelenerek mezbele haline getirdikleri bu mekânı Müslümanlarla birlikte temizlemiş ve Hz. Dâvûd'un mihrabında namaz kılmıştır. ${ }^{66} \mathrm{~Hz}$. Ömer Hz. Dâvûd'un mihrabında/Allah Resûlü'nün namaz kıldığ 1 yerde ${ }^{67}$ tahiyyetü’lmescid namazı kılmıştır. ${ }^{68}$ Ertesi gün de Müslümanlara sabah namazı kıldırmış, birinci rekâtte Sâd suresini, ikinci rekâtte ise İsrâ suresini okumuştur. ${ }^{69}$

60 Tanyu, I, 474-75; Salah, “Aksâ Tehlikede”, s. 22, 27.

61 Nitekim Hz. Dâvûd, Sahre’nin (hacer-i muallak) üzerine bir mescid yapmakla emrolunmuştur. Bkz. İbn Asâkir, Ebu'l-Kasım Ali b. Hasan, Târîhu Medînet-i Dımaşk, thk. Muhibbuddin Ebu Saîd Ömer b. Garâme el-Amrevî, Beyrut, 1995, XXVI, 368. Ayrıca bkz. Nebi Bozkurt, "Kubbetü’s-Sahre”, DİA, XXVI, 305. Buna göre Mescid-i Aksânın mekânı bellidir.

62 Zerkeşî, s. 277; Âyiş Abîd, s. 212-13. Bu konuda tafsılatlı bilgi için bkz. Altun, "Hz. Peygamber döneminde Kudüs'te Mescid-i Aksâ Var mıydı?” s.8, 15.

63 İbn Kesîr, el-Bidâye, IX, 656; Abdu'l-Kerim, Kitâbu'l-Mescidi'l-Aksâ, s. 20-23; Özcan, "Mescid-i Aksâ ve Üçüncü Mabedin Kaderi”, s. 65-66.

64 Mucîruddîn el-Hanbelî, el-Ünsü'l-Celîl bi Târîhi'l-Kuds ve'l-Halîl, I, 226-27; el-Khatip, Abdullah, Kur'an'da Kudüs, çeviren: Ramazan Işık, Fırat Üniversitesi İlahiyat Fakültesi Dergisi, 2004, cilt: IX, sayı: 1, ss. 109-143, s. 121.

65 İbn Kesîr, el-Bidâye, IX, 656. Musevilere, Hiristiyanlara ve Müslümanlara göre Kudüs’ün en kutsal bölümü, eski kentin doğu tarafında duvarlarla ayrılmış ve zemini yükseltilmiş 300x480m. genişliğindeki bir sahanlık üzerinde bulunan kısımdır. Bu alan Harem-i Şerif adıyla anılmıştır. Bkz. F. Buhl, “Kudüs” İA, VI, 953. İslâm’ın ilk dönemlerinde Mescid-i Aksâ tabiri ile özellikle Harem-i șerif'in tamamı kastedilmiștir. Bkz. Ahmed Mahmud Şefik, Târîhu’l-Kuds, Amman, 1984, 200-201; Harman, “Kudüs”, DİA, XXVI, 324. Dolayısıla Harem-i Şerif’in/Mescid'in etrafı surlarla kaplıdır ve Harem alanının içine kapılardan girilmektedir.

66 Mucîruddîn el-Hanbelî, el-Ünsü'l-Celîl bi Târîhi'l-Kuds ve'l-Halîl, I, 226-27; el-Khatip, Abdullah, Kur'an'da Kudüs, s. 121.

67 Ahmed b. Hanbel, Müsned, I, 38; İbn Kesîr, el-Bidâye, IX, 662, 656; Abdu’l-Kerim, Kitâbu'l-Mescidi'l-Aksâ, s. 20-23; Özcan, "Mescid-i Aksâ ve Üçüncü Mabedin Kaderi”, s. 65-66.

68 İbn Kesîr, el-Bidâye, IX, 656; Abdu'l-Kerim, Kitâbu'l-Mescidil-Aksâ, s. 20-23; Özcan, "Mescid-i Aksâ ve Üçüncü Mabedin Kaderi", s. 65-66.

69 İbn Kesîr, el-Bidâye, IX, 656; Abdu'l-Kerim, Kitâbu'l-Mescidi'l-Aksâ, s. 20-23; Özcan, “Mescid-i Aksâ ve Üçüncü Mabedin Kaderi”, s. 65-66. Benzer ifadeler için bkz. Taberî, Târîh, III, 611 (I, 2409). 
Öğlen namazı vakti geldiğinde ise Hz. Ömer, Bilal-i Habeşi'den Mescid-i Aksâda ezan okumasını istemiştir. ${ }^{70}$ Bunun üzerine Hz. Bilal (ra), Mescid-i Aksâda ezan okumuş, onun sesini duyan sahabiler Allah Resûlü'nü hatırlamış ve gözyaşlarına hâkim olamamışlardır. ${ }^{71}$

Bütün bunlar, o tarihte Kudüse ayrı bir önem verildiğini ve Allah Resûlü’nün namaz kıldığı yere varıncaya kadar Kudüs'e dair birçok şeyin sahabiler tarafından bilindiğini göstermektedir. Bu sebepledir ki Hz. Peygamber döneminden itibaren Abdullah b. Ömer başta olmak üzere ${ }^{72}$ Ebû Ubeyde, Muâz b. Cebel, Bilâl b. Rabâh, Temîm b. Uveys ed-Dârî ve Abdullah b. Selâm gibi sahabiler ibadet ve ziyaret maksadıyla Mescid-i Aksầya yolculuk yapmışlardır. ${ }^{73}$

Halife Hz. Ömer dönemine kadar Beytü'l-Makdis’te yeniden bir mescit inşası için hiçbir girişimde bulunulmamıştır. ${ }^{74}$ Kudüs'ün fethinden sonra Hz. Ömer, Mescid-i Aksẩnın yerini tesbit ettirerek burada ahşaptan ${ }^{75} 3000$ kişinin namaz kılabilldiği büyük bir mescid yaptırmıştır. ${ }^{76}$ Mezkûr mescid, Kumâme Kilisesi’ne bitişik olarak inşa edilmiştir. Hz. Ömer, burada bir hafta kadar da ibadet etmiştir. Caminin doğu tarafı köşesinde Hz. Ömer mihrabı, onun hemen yakınında Hz. Dâvûd mihrabı bulunmaktadır. Minberin sağında ise Hz. Îsâ makamı yer almaktadır. Evliya Çelebi, Cuma günü hatiplerin minbere kılıç ile çıktıklarını ve bu kılıcın Hz. Ömer'in kılıcı olduğunu kaydetmektedir. ${ }^{77}$ İbn Teymiye, Hz. Ömer'in bu mescidi Mescid-i Aksẩnın ön tarafında bina ettiğini ve bazı insanların buraya el-Aksâ ismini verdiklerini belirtmektedir. ${ }^{78}$

Mescid-i Aksâ Hz. Ömer döneminden sonra Emevilerin de ilgi odağı haline gelmiş ve bu dönemde Mescid-i Aksâ yeniden inşa edilmiştir. Bunun arkasından Mescid-i Aksânın imar ve himaye aşamaları devam etmiştir. ${ }^{79}$ Şunu da belirtmek gerekir ki âlimlere ve tarihçilere göre Hz. Süleyman’ın bina ettiği Mescid-i Aksâ, bu gün bu isimle anılan binadan daha kapsamlıydı. Kapıları bulunan büyük surların iç kısmında kalan alanın tamamına şe’rî anlamda mescid adı verilirdi. ${ }^{80}$ Günümüzde

70 Mucîruddîn el-Hanbelî, el-Ünsü'l-Celîl bi Târîhi'l-Kuds ve'l-Halîl, I, 228; Ağırakça, Ahmet, "Kudüs ve Mescid-i Aksâ’nın İslâm'daki Yeri” Mescid-i Aksâ Sempozyumu, İstanbul Barış Platformu, İstanbul, 2009, s. 86.

71 Mucîruddîn el-Hanbelî, el-Ünsü’l-Celîl bi Târîhi'l-Kuds ve’l-Halîl, I, 228.

72 İbn Teymiye, Mecmû-ul-Fetâvâ, XXVII, 141.

73 Mucîruddîn el-Hanbelî, el-Ünsü'l-Celîl bi Târîhi'l-Kuds ve’l-Halîl, I, 231-37; Hicazi, Şia ve Mescid-i Aksâ, s. 54, 57. Ayrıca bkz. Ahmet Güç, "Yeryüzünde Üç Büyük Mescid”, Uludağ Üniversitesi İlahiyat Fakültesi Dergisi, 1993, cilt: V, sayı: 5, s. 270.

74 Salah, "Aksâ Tehlikede", s. 22-23.

75 Salah, "Aksâ Tehlikede", s. 22-23.

76 F. Buhl, "Kudüs” İA, VI, 956; Önkal-Bozkurt, “Cami”, DİA, VII, 48.

77 Evliya Çelebi, s. 566, 568.

78 İbn Teymiye, Mecmû-ul-Fetâvâ, XXVII, 11.

79 Salah, "Aksâ Tehlikede", s. 22-23. Bazı rivayetlerde, Mescid-i Aksẩnın ikinci defa Emevî Halifesi Abdu'l-Melik b. Mervân tarafından inșa edildiği belirtiliyorsa da 90-96 (709-714) yıllarında Mısır valiliği yapan Kurre b. Şerîk dönemine ait Grekçe divan kayıtlarından binayı yaptıranın I. Velîd olduğu anlaşılmaktadır. Bkz. Bozkurt, "Mescid-i Aksâ", DİA, XXIX, 270.

80 Muhammed Abdu'l-Kerim, Kitâbu'l-Mescidi’l-Aksâ, s. 10. 
Müslümanların "Burak Duvarı" Yahudilerin ise "Ağlama Duvarı" olarak adlandırdıkları duvar, Kral Herod/Hirodes'in yaptırdığı mâbedin çevresini kuşatan duvarın bir kısmıyd. Burası tarihte "Burak Duvarı" diye bilinmekteydi. Fakat daha sonra Kudüs'ü ele geçirme emelinin ön adımlarından biri olarak siyonistler tarafından "Ağlama Duvarı" olarak adlandırılmıştır. ${ }^{81}$ Bugünkü haliyle duvarın en üstünde bulunan on bir sıra, İslâmî dönemden kalmadır. Geri kalan kısım ise Hz. Süleyman döneminden kalma olmayıp Herod dönemi mimari özelliklerini taşımaktadır. Ancak Yahudiler bu duvarı Süleyman Mâbedi’nden bir kalıntı kabul ettikleri için kutsal bir mekân saymaktadırlar. ${ }^{82}$

\section{Değerlendirme ve Sonuç}

Kur'an-1 Kerim'de, Kudüs ismi doğrudan zikredilmese de birçok ayet-i kerimenin bu kutsal toprakları konu aldığ 1 anlaşılmakta ve bu ayet-i kerimelerde mezkûr toprakların mübarek ve mukaddes kılındığı beyan edilmektedir. Kudüs topraklarının bereketli kılındığını ifade eden ayetlerin tamamı Mekkîdir. Bu toprakları el-Ardu’lMukaddese diye vasıflandıran ayet ise Medenîdir. ${ }^{83} \mathrm{Bu}$ iki vasıf kullanılmaksızın Kudüs'e işaret eden daha başka Mekkî ve Medenî ayetler de vardır. ${ }^{84}$ Özellikle Kudüs’ten mübarek topraklar diye söz eden ayetlerin Mekkî olması, Kur'an’ın, bu toprağın ehemmiyetini Medine’ye hicretten çok önce sahabeye bildirdiğini göstermesi bakımından calib-i dikkattir. Kezâ sahabilerin, Mekke döneminden itibaren namazlarını Beytü’l-Makdis’e yönelerek kılmaları, Kudüs tarihinin Müslümanlar için risaletin ilk yıllarından itibaren başladığını ve dolayısıyla Kudüs'ün, İslâmiyetin doğuşundan itibaren ümmetin vicdanında yaşamakta olduğunu ortaya koyması açısından önemlidir. İsrâ hadisesinin ise sahabenin vicdanında yaşayan Kudüs sevgisini iyice pekiştirdiği anlaşılmaktadır. Bunlara ilaveten Resûlullah’ın, Beytü'l-Makdis'in yakında fethedileceğini müjdelemesi ve mahza namaz kılmak niyetiyle Mescid-i Aksầya gelenlerin bağışlanacağını haber vermesi, sahabenin Kudüs ü fethetmeyi gaye edinmelerinin sebepleri arasında zikredilebilir. Bunun içindir ki sahabiler, Kudüs topraklarının fethedilmesi yolunda ellerinden gelen her şeyi yapmayı görev telakki etmişlerdir. Sahabenin bu çabası Hz. Ömer'in hilafeti döneminde sonuç vermiş ve Kudüs, fethedilerek İslâm topraklarına dâhil edilmiştir. Böylece sahabiler, Kudüs'ün fethini isteyen ve müjdeleyen Resûlullah’a olan bağlılıklarını ortaya koymuşlardır.

Yukarıda da belirtildiği üzere Kudüs'ün fethinden hemen sonra Hz. Ömer ilk olarak, daha önceki dönemlerde tahrip edilen ancak temelleri bulunan ve mekânı bilinen Mescid-i Aksânın yerini araştırmaya ve soruşturmaya başlamıştır. Mescidin yerini tespit eden halife, kapıları bulunan büyük surların iç kısmında yer alan bu

81 Salah, "Aksâ Tehlikede", s. 22, 27.

82 Bkz. Tanyu, "Ağlama Duvarı", DİA, I, 474-75.

83 5. Mâide, 21.

84 Bkz. 2. Bakara, 58, 259; 3. Âl-i İmran, 37-39; 10. Yunus, 93; 19. Meryem, 16-17; 23. Muminun, 50. Bakara ve Al-i İmran surelerinde yer alan ayetler hariç diğerleri yine Mekkî̀dir. 
Mescide özellikle Resûlullah’n girdiği kapıdan girmeyi tercih etmiş ve Mescidi görünce tekbir getirmiştir. Arkasından bu Mescidin, Resûlullah (as)'in kendilerine anlattığı Mescidin ta kendisi olduğunu vurgulamıştır. Bu tür rivayetlerden İsrâ gecesi Resûlullah’ın Kudüse yürütüldügü ve Mescid-i Aksânın özellikleri hakkında Hz. Peygamber tarafından sahabeye daha önce bilgi verildiği anlaşılmaktadır.

Bilahare Hz. Ömer, Rumların mezbeleye çevirdikleri bu mekânı Müslümanlarla birlikte temizlemiş ve Allah Resulü’nün namaz kıldığ 1 yerde gerek münferit, gerek cemaatle namaz kılmıştır. Bilal-i Habeşiye de Mescid-i Aksâdda ezan okutmuştur. Ayrıca Hz. Ömer, Mescid-i Aksẩnın ön tarafında büyük bir mescid yaptırmış, burada bir hafta kadar da ibadet etmiştir. Sahabilerden bir kısmı da ibadet ve ziyaret maksadıyla Mescid-i Aksâya yolculuklar yapmışlardır. Görülüyor ki sahabe, gerek fetihten önce gerekse fetihten sonra Kudüs'e ve hususen Mescid-i Aksầya fevkalâde önem vermiştir. Allah Resûlü’nün namaz kıldığı yere varıncaya kadar Mescid-i Aksầya dair birçok şeyi araştırma ve tespit etme hususunda sahabenin ciddi gayretleri olmuştur.

$\mathrm{Bu}$ sebeple fetih esnasında $\mathrm{Hz}$. Ömer'in ve sahabenin, Kudüs’e özel ilgi göstermediklerine, buraya hususi bir bölge muamelesi yapmadıklarına ve bu hususla ilgili kaynaklarda herhangi bir bilginin yer almadığına dair ileri sürülen iddiaların temelsiz olduğu anlaşılmaktadır. Yine erken dönemlerde Müslümanların İsrâ hadisesine fazla önem vermediklerine, sonraki dönemlerde bu hadisenin fazla önemsenmeye başladığına veya Müslümanların Emevi halifesi Abdu'l-Melik b. Mervan döneminden itibaren Kudüse önem vermeye başladıklarına ilişkin bir kısım araştırmacıların ve oryantalistlerin açıktan veya imalı bir şekilde ileri sürdükleri argümanların doğru olmadığı ortaya çıkmaktadır. Kezâ Kudüs’ün fethi sırasında halife Hz. Ömer'in ve sahabenin Mescidi Aksâyı bulma ve yerini belirleme konusunda bir gayretlerinin olmadığına ilişkin iddiaların da isabetli olmadığı idraklere yansımaktadır. Bu tür görüş ve iddiaların ciddi araştırmaların ürünü olmadığı, sathî bilgilerden ve önyargılardan kaynaklandığı ya da maksatlı olarak ortaya atıldı̆̆ 1 açıktır.

Sonuç olarak diyebiliriz ki, sahabe mukaddes şehir Kudüse ve etrafı mübarek kılınmış Mescid-i Aksâya Mekke döneminden itibaren büyük ehemmiyet vermiştir. Dolayısıyla sahabenin Kudüs'le ilişkisinin risalet kadar eski olduğu anlaşılmaktadır. Risaletin ilk yıllarından bu yana bu mukaddes topraklara gösterilen yakın ilgi ve alakanın günümüze kadar süregeldiğini de belirtmek gerekir. Dün olduğu gibi bugün de İslâm âlemi Kudüs'ün kutsiyetine inanmakta ve yıllardır işgal altındaki bu mübarek beldenin tekrar özgürlüğüne kavuşmasını beklemekte ve ümit etmektedir. 


\section{Kaynakça}

Abdu'l-Kerim, Muhammed, Kitâbu'l-Mescidi'l-Aksâ, byy, tsz.

Abdu'r-Rezzâk, Ebû Bekir, es-Sanânî, el-Musannef, thk. Habîburrahman el-A'zamî, Beyrut, 1983.

Ağırakça, Ahmet, "Kudüs ve Mescid-i Aksẩnın İslâm'daki Yeri” Mescid-i Aksâ Sempozyumu, İstanbul Barış Platformu, İstanbul, 2009.

Ahmed b. Hanbel, Müsned, thk. Şuayb Arnavut-Adil Mürşid, Beyrut, 1995.

Ahmed Ömer Haşim, el-Mescidü'l-Aksâ ve Mekânetuhu fi'l-İslâm, Mecelletü'l-Ezher, 53/7, Kahire, 1981.

Altun, İsmail, "Hz. Peygamber döneminde Kudüs'te Mescid-i Aksâ Var mıydı?" Turkish Studies, Karşılaştırmalı Dinî Araştırmalar (Comparative Religious Studies), Ankara-Winter 2017, ss. 1-22.

Azimli, Mehmet, Siyeri Farkl Okumak, Mekke Yılları, Ankara Okulu Yayınları, Ankara, 2010.

, İsrâ ve Miraç Olayları Üzerine Bazı Mülahazalar, Bilimname: Düşünce Platformu, 2009/1, cilt: VII, sayı: 16, s. 43-58.

Balc1, İsrâfil, İsrâ ve Mirâc Gerçeği, Ankara, 2014.

Belâzürî, Ebu'l-Abbas Ahmed b. Yahya, Fütûhu'l-Büldân, thk. Abdullah Enis et-Tübbâ'-Ömer Enis et-Tübbâ’, Beyrut, 1987.

Bozkurt, Nebi, "Kubbetü’s-Sahre”, DİA, 2002, XXVI, 305. , "Mescid-i Aksâ", DİA, Ankara, 2004, XXIX, 270.

Buhari, Muhammed b. İsmâîl, Sahîhu'l-Buhârî, İstanbul, 1315/1897.

Buhl, F., “Kudüs” İA, İstanbul, 1993, VI, 953-56.

Cabarin, Raid Fethi Halid, "Tarihî Süreçte Mescid-i Aksâ”, Çağdaş Araştırmalar Merkezi (Merkez Dirasat al-Muasarah) Arapçadan çev. Suna Demir, Mescid-i Aksâ Sempozyumu, İstanbul Barış Platformu, İstanbul, 2009, s. 37-49.

Demirci, Muhammed, "Kudus'ün Kısa Tarihi ve Hz. Ömer'in Emannamesi” Mescidi Aksâ Sempozyumu, İstanbul Barış Platformu, İstanbul, 2009, s. 95-96.

Ebû Adirrahman es-Selefî, İsâdu’l-Ahissâ bi Zikri Sahihi Fedâilişs-Şâm ve'l-Mescidi'lAksâ, byy., tsz.

Ebû Dâvûd, Süleyman b. el-Eş’as es-Sicistanî, Sünen, Kahire, 1988. 
Evliya Çelebi, Seyahatname (Kısaltılmış Versiyon), Sadeleştirerek çev. Tevfik Temelkuran-Necati Aktaş- Mümin Çevik), İstanbul, 2006.

Goldziher, I., Muslim Studies, İngilizceye çev. C. R. Barber-S. M. Stern, New York Üniversitesi Yayınları, İngiltere, 1971.

Güç, Ahmet, "Yeryüzünde Üç Büyük Mescid”, Uludağ Üniversitesi İlahiyat Fakültesi Dergisi, 1993, cilt: V, sayı: 5.

Harman, Ömer Faruk, "Kudüs”, DİA, Ankara, 2002, XXVI, 324-27.

Heysemî, Nureddin Ali b. Ebî Bekr, Mecmau'z-Zevâid ve Menbau'l-Fevâid, Beyrut, 1967.

Hicazi, Tarık Ahmed, Şia ve Mescid-i Aksâ, Konya, 2010.

Horovitz, J., 'Mi'râc', İA, İstanbul, 1979, VIII, 344-45.

el-Khatip, Abdullah, Kur’an'da Kudüs, çeviren: Ramazan Işık, Fırat Üniversitesi İlahiyat Fakültesi Dergisi, 2004, cilt: IX, sayı: 1, ss. 109-143.

İbn Asâkir, Ebu'l-Kasım Ali b. Hasan, Târîћu Medînet-i Dımaşk, thk. Muhibbuddin Ebu Saîd Ömer b. Garâme el-Amrevî, Beyrut, 1995.

İbn Ebî Şeybe, Ebu Bekir Abdullah b. Muhammed, el-Musannef, thk. Muammed Avvâme, Beyrut, 2006.

İbn Kesir, Ebu'l-Fida İsmail, Tefsîru'l-Kurâni'l-Azîm, thk. Mustafa Seyyid Muhammed ve Arkadaşları, Kahire, 2000. 1998.

İbn Mâce, Ebû Abdillah Muhammed b. Yezîd, Sünen, İstanbul,1981.

İbn Teymiye, Mecmû'u'l-Fetâvâ, thk. Amir el-Cezzar, byy, 2005.

İbnu'l-Cevzî, Cemalüddin Ebu'l-Ferec, Târîhu Beyti'l-Makdis, byy, tsz. , Cemalüddin Ebu'l-Ferec, Fedâilü'l-Kuds, thk, Cebrail Süleyman, Beyrut, 1980.

Karadavi, Yusuf, Her Müslümanın Ortak Davası Kudüs, Nida Yayıncılık, İstanbul, 2010.

Koçyiğit, Talat, I. Goldziher'in Hadisle İlgili Bazı Görüşlerinin Tahlil ve Tenkidi, Ankara Üniversitesi İlahiyat Fakültesi Dergisi, 1967, cilt: XV, s. 43-55.

Kurtubi, Ebu Abdillah Muhammed, el-Câmiu'l-Ahkâmi'l-Kur'ân, thk. Abdullah b. Abdu'l-Muhsin et-Türkî, Beyrut, 2006. 
Makdisî, Ziyauddin Muhammed, Fedâilu Beyti'l-Makdis, thk. Muhammed Mutî’ elHâfiz, Dâru'l-Fikr, Dımaşk, 1405, s. 69.

Malik b. Enes, Muvatta, thk. Muhammed Mustafa el-A'zamî, byy, 2004.

Mucîruddîn el-Hanbelî, el-Ünsül-Celîl bi Târîhi'l-Kuds ve’l-Halîl, Amman, 1999.

Müslim, Ebü'l-Hüseyn b. Haccâc, Sahîhu Müslim, Riyad, 1998.

Nesâî, Ahmed b. Şu’ayb, Sünen, thk. Abdu’l-Fettah Ebû Ğudde, Haleb, 1986.

Önkal, Ahmet - Bozkurt, Nebi, “Cami”, DİA, İstanbul, 1993, VII, 47-48.

Özcan, Mustafa , "Mescid-i Aksâ ve Üçüncü Mabedin Kaderi” Mescid-i Aksâ Sempozyumu, İstanbul Barı̧ Platformu, İstanbul, 2009.

Salah, Raid, "Aksâ Tehlikede", çev. Mustafa Salah, Mescid-i Aksâ Sempozyumu, İstanbul Barı̧ Platformu, İstanbul, 2009.

Schrieke, B., 'İsrầ, İA, İstanbul, 1979, V/II, 1126.

Söylemez, Mahfuz, Kudüs ve Osmanlı Arşiv Vesikaları Işı̆̆ında Yahudilerin Bölgeye Yerleşmeleri Üzerine Notlar, Siirt Üniversitesi iİahiyat Fakültesi Dergisi, cilt: 1, say1 2, ss. 33-56.

Şefik, Ahmed Mahmud, Târîhu'l-Kuds, Amman, 1984.

Taberî, Ebû Cafer Mummed b. Cerîr, Târîhu'r-Rusûl ve'l-Mulûk, thk. Muhammed Ebu'l-Fadl İbrahim, Kahire, 1119.

Tanyu, Hikmet, “Ağlama Duvarı", DİA, İstanbul, 1988, I, 474-75.

Tirmizî, Ebû İsa Muhammed b. İsâ, Sünen (nşr. Ahmed Muhammed Şâkir), İstanbul 1981.

Wellhausen, J., Arap Devleti ve Sukutu, çev. Fikret Işıltan; İlahiyat Fakültesi Yayınlarından, Ankara 1963.

Ya’kûbî, Târîhu'l-Ya'kûbî, thk. Abdu'l-Emîr Mihnâ, Beyrut, 1993.

Zemahşerî, Ebu'l-Kasım Mahmud b. Ömer, el-Keş̧̧âf an Hakaiki Ğavamidi't-Tenzîl ve Uyûni'l-Ekavîl fî̀ Vucûhi't-Te'vîl, thk. Adil Ahmed-Ali Muhammed, Riyad, 1998.

Zerkeşî, Muhammed b. Abdillah, I'lâmu's-Sâcid bi Ahkâmi'l-Mesâcid, thk. Ebu'lVefa Mustafa el-Merâğ̂̀, Kahire, 1999. 
170 - ilahiyat Yıl: 2017 | Sayl: 47 


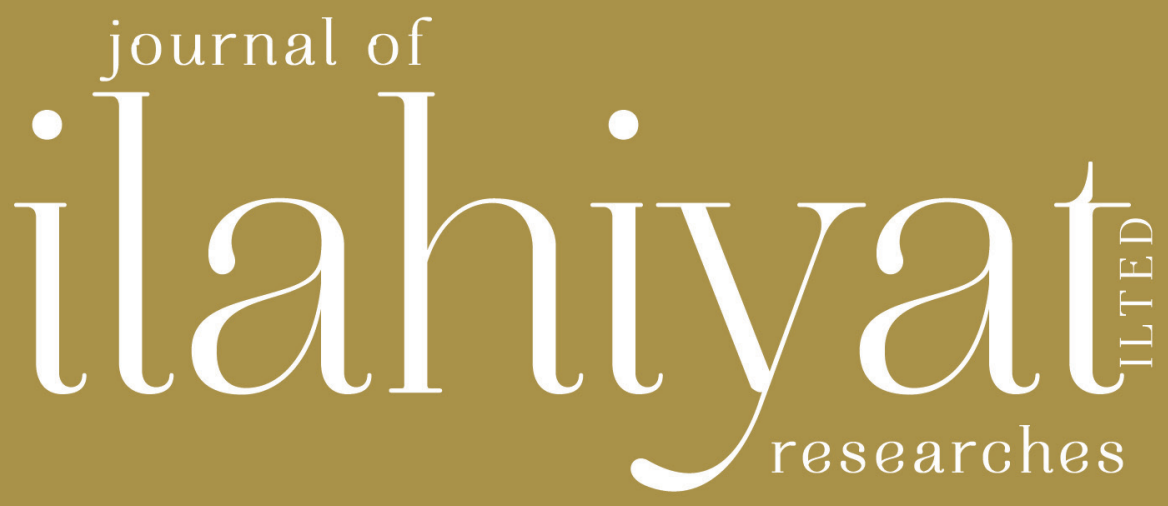

ilahiyat tetkikleri dergisi 